\title{
Sir James Wylie, The Russian McGrigor
}

Great Britain had a remarkable medical connection with Russia over several centuries. Queen Elizabeth 1 sent Dr Jacob to the Russian court of the day, and in her letter of introduction recommended him as one skilled in midwifery and diseases peculiar to women. Dr Marcus Ridley of Cambridge followed soon after, returning to England after a four year tour. Dr Marcus Ridley, of Alva in Scotland, was personal physician to Peter the Great in the early 18 th century - and it may have been the Czar's visit to Greenwich in 1698 which helped to form in his mind the idea of founding a military hospital in his own country. Among his very many interests, Peter the Great included army medical staffing and he issued a ukase specifying the establishment of medical officers for the Russian Army. Each division was to have a physician and a staff surgeon. Each regiment was to have a surgeon and every company a felcher - or as the British called him, a surgeon's mate. Two large medicine chests were to be provided for the army. To each of those were attached one apothecary, two assistants and four apprentices. A similar scale was laid down for the navy.

However, by the later 18th century this provision had lapsed. We had the same phenomenon in the Royal Navy after Lind retired; all his advances and new thinking

Dr JSG Blair OBE KStJ TD TAVRD BA ChM

DLitt (honoris causa;St Andrews) FRCS FRCP DRCOG FRHistS FSA (Scot)

World Vice President, International Society for the History of Medicine

Editorial Director, ISHM Journal

The Brae, 143 Glasgow Road, Perth, PH2 OLX were quickly lost. At this time in Russia only officers, and senior ones at that, had any medical provision made for them. In Tolstoy's 'War and Peace', when the wounded Prince Andrew was carried away, he took his doctor with him. Other wounded officers took medical officers away to look after them as they wished - in this they behaved as did the consuls in the days of Republican Rome. No provision - apart it must be said from help by lower clergy - existed for noncommissioned officers and common soldiers. One of Wylie's greatest achievements was to re-establish an Army Medical Service and to go farther - to insist on provision being made for the care of the rank and file.

Wylie was born of poor parents, William Wylie and Janet Meiklejohn, in a small town called Kincardine-on-Forth in 1768. His mother, a strong minded and devout woman was the character builder of the family. As a youth he was apprenticed to a local doctor and, being badly treated by him, tried to run off to sea. His mother caught him and brought him home. $\mathrm{He}$ then went to Edinburgh University, both as an apprentice and to attend classes. It took great determination to get an MD, but determination was one of Wylie's greatest virtues.

His move to Russia was helped by a slice of good luck. He first became medical attendant to the Galitzin family, then surgeon to the Eletsky Regiment. At the time, Czar Paul had ennobled one of his lower servants and Wylie was fortunate to treat this man, Count Kutaisoff, for an abscess in the throat which he boldly incised after several doctors had failed to treat him. $\mathrm{He}$ was at once raised by the Czar to the position of court physician. Other cases, equally fortunate for Wylie, occurred soon afterwards. With his position came riches and power.

Wylie was present at the murder of Czar Paul and wrote the death certificate. $\mathrm{He}$ became a favourite of Paul's successor, Czar Alexander 1, and subsequently accompainied him on all his travels, finally as his surgeon general. He was present at Borodino and is said to have carried out 200 amputations there. He witnessed, with the Czar, the scenes at Wilma in 1812. During the retreat from Moscow he obtained, as loot, a pair of pistols said to be taken from 


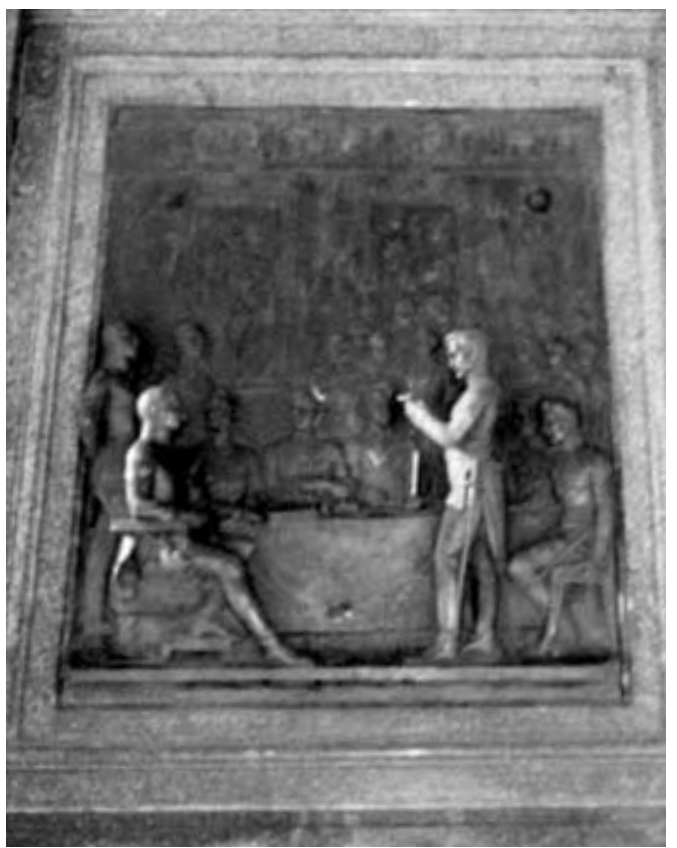

Napoleon's carriage. At Dresden in 1813 he amputated Moreau's shattered legs, but refused to amputate the Emperor's.

Vilje, as he was now called, accompanied Alexander on his journey to the Crimea and again was one of those who treated him in his last illness. He retained his place under Czar Nicholas, and died in St Petersburg in 1854 at the age of 86 . It was in St Petersburg that the Military Academy had been founded in 1799 - its purpose to train doctors for the navy and army - and its foundation and development were largely due to Vilje's far-sighted planning and encouragement. Much of the money needed he supplied from his own fortune. $\mathrm{He}$ did all the things which his fellow Scot, Sir James McGrigor (1771-1858) did in Britain - choosing entrants, supervising their training and maintaining high standards. His statue broods over the Medical College in St Petersburg today, just as McGrigor's did at Millbank. Vilje, like McGrigor, was awarded an MD by Aberdeen University, his in 1794.

Hard work and determination got Wylie his personal position. It was his Scots background of independence and insistence on high standards - his Presbyterian ethic with its insistence on the worth of the

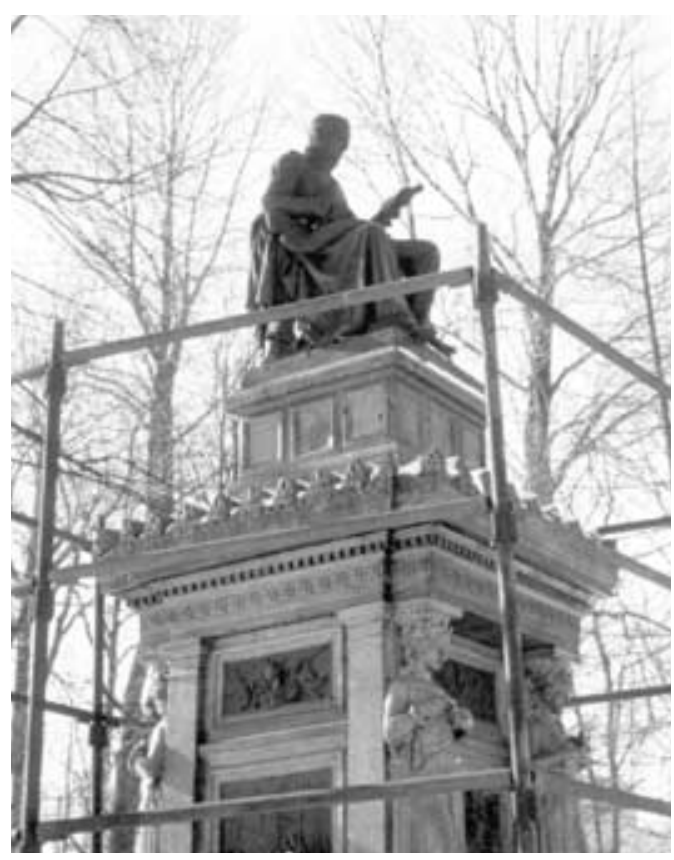

poorest - that made his name as the Russian Surgeon General from Scotland.

It was well known that he also had less likeable Scottish attributes. He was said to be solitary, mean, and what Scots call 'dour', with 'little refinement of manners'. $\mathrm{He}$ never married. He was personally brave wounded three times - and was loyal. $\mathrm{He}$ was careful, diligent and perhaps rather unimaginative in his clinical practice - as are many lowland Scots. He treated enemy casualties also and brought humanity where it was missing before. Where he was unlike the typical Scot was in his total identification with the land which adopted him, and while his brother visited him in Russia, he never returned to Scotland. His papers were written in French and Russian. He even forgot the language of his birth. He remains revered by his Russian successors, as I recall from talking to them when I visited Moscow some years ago.

\section{References:}

Richter, WM Geshichte der Medizen in Russland, 1813.

Hutchison, Sir Robert, Proc R. Soc. Med, 21, 1406. 1928.

Blair, JSG, James Wylie, the Russian Surgeon General from Scotland,

Russian Academy of Medical Sciences, August, 1991. 